\title{
Hubungan Kepribadian Hardiness Dengan Regulasi Emosi Pada Dokter Spesialis Yang Pernah Menangani Pasien Meninggal Dunia
}

\author{
Yobella Christiani Wahono \\ Krismi Diah Ambarwati \\ Fakultas Psikologi Universitas Kristen Satya Wacana Salatiga \\ yobellacw@gmail.com
}

\begin{abstract}
Abstrak
Penelitian ini bertujuan untuk mengetahui hubungan antara kepribadian hardiness dengan regulasi emosi pada dokter spesialis yang pernah menangani pasien meninggal dunia. Subjek penelitian ini berjumlah 40 dokter spesialis yang pernah menangani pasien meninggal dunia dan memenuhi karakteristik yang telah ditentukan. Metode Dalam penelitian ini menggunakan pendekatan kuantitatif dengan desain penelitian korelasional. Variabel bebas $(X)$ adalah kepribadian hardiness dan variabel terikat $(Y)$ adalah regulasi emosi berdasarkan aspek yang dikemukakan oleh Kobasa dan diadaptasi oleh Lukman (2008), dan skala Emotion Regulation Questionnaire (ERQ) yang disusun oleh John dan Gross (2003). Berdasarkan hasil penelitian diperoleh nilai koefisien korelasi kepribadian hardiness dan regulasi emosisebesar 0,$492 ;(p)=0,001(p<0,05)$. Hasil analisis menunjukkan bahwa hipotesis diterima yakni terdapat hubungan positif yang siginifikan antara kepribadian hardiness dengan regulasi emosi pada dokter spesialis yang pernah menangani pasien meninggal dunia yang artinya semakin tinggi kepribadian hardiness pada dokter spesialis maka semakin tinggi regulasi emosi pada dokter spesialis.
\end{abstract}

Kata kunci: Kepribadian Hardiness, Regulasi Emosi, Dokter Spesialis, Pasien Meninggal Dunia

\begin{abstract}
This study aims to determine the relationship between hardiness personality and emotion regulation on specialists who have treated patients who have died. The subject of this study amounted to 40 specialists who had handled a dying patient and fulfilled predetermined characteristics. Methods In this study using a quantitative approach with correlational research design. The independent variable $(X)$ is hardiness personality and the dependent variable $(Y)$ is emotion regulation based on aspects expressed by Kobasa and adapted by Lukman (2008), and the Emotion Regulation Questionnaire (ERQ) scale compiled by John and Gross (2003). Based on the results of the study, it was found that the hardiness personality correlation coefficient and emulation regulation were 0.492; $(p)=0.001(p<0.05)$. The results of the analysis show that the hypothesis is accepted, namely there is a significant positive relationship between hardiness personality and emotion regulation on specialists who have treated patients who died, which means that the higher the hardiness personality of specialists, the higher the regulation of emotion to specialist doctors.
\end{abstract}

Keywords: Hardiness Personality, Emotional Regulation, Specialist Doctor, Patient Died

(C) 2018 Universitas Muria Kudus 


\section{PENDAHULUAN}

Kebutuhan akan kesehatan pada masyarakat modern sekarang semakin kompleks. Hal tersebut dapat memengaruhi para praktisi kesehatan dalam memberikan pelayanan kesehatan kepada masyarakat. Berdasarkan Peraturan Menteri Kesehatan Republik Indonesia No. 659/MENKES/PER/VIII/2009 tentang Rumah Sakit Indonesia kelas dunia, rumah sakit adalah fasilitas pelayanan kesehatan yang menyelenggarakan pelayanan kesehatan perorangan secara paripurna yang menyediakan pelayanan rawat inap, rawat jalan, dan gawat darurat. Rumah sakit diharapkan dapat memberikan pelayanan kesehatan kepada masyarakat dengan baik. Oleh karena itu, untuk mewujudkan tujuan tersebut diperlukan tenaga medis yang mampu memberikan pelayanan kesehatan kepada masyarakat.

Dokter merupakan salah satu tenaga medis di rumah sakit yang memberikan pelayanan untuk menunjang kesembuhan pasien. Seorang dokter merupakan elemen terpenting di rumah sakit sehingga dibutuhkan dedikasi yang tinggi untuk menyelesaikan permasalahan kesehatan masyarakat secara harfiah juga praktisnya (Pangesti, 2012). Dokter adalah sosok yang cukup menjadi tumpuan masyarakat dalam hal kesehatan, terutama dalam proses penyembuhan penyakit.

WHO menerapkan batasan bahwa dokter masa depan wajib memenuhi kriteria lima kualitas seorang dokter (Five Star Doctor) yang salah satunya adalah sebagai Care Provider yaitu dalam memberikan pelayanan medis, seorang dokter hendaknya memperlakukan pasien secara holistik, memandang individu sebagai bagian integral dari keluarga dan komunitas, memberikan pelayanan yang bermutu, menyeluruh, berkelanjutan dan manusiawi dan dilandasi hubungan jangka panjang dan saling percaya.

Berdasarkan hasil wawancara singkat yang peneliti lakukan terhadap dua orang dokter spesialis pada 22 Februari 2018 diperoleh bahwa masing-masing individu sebagai dokter spesialis dituntut untuk selalu bersikap baik dan ramah di depan pasiennya untuk memenuhi kesejahteraan pasien-pasiennya dan agar kualitas pelayanan kesehatan yang diberikan semakin meningkat. Masing-masing individu juga merasakan adanya tekanan, permasalahan, dan tuntutan yang mereka hadapi. Berbagai alasan melatarbelakangi dokter spesialis merasakan adanya tekanan dan tuntutan. Salah satunya karena dokter spesialis dihadapkan dengan risiko pasien yang meninggal dunia yang bisa disebabkan oleh kondisi kesehatan pasien yang buruk akibat kejadian tidak terduga seperti kecelakaan maupun penyakit kronik dan kondisi terminal. Pasien terminal adalah pasien-pasien yang dirawat, yang sudah jelas bahwa mereka akan meninggal atau keadaan mereka makin lama makin memburuk (Stevens, Bordui, Van Der Weyde, 1999). 
Menurut Badan Pusat Statistik Indonesia pada hasil survei tahun 2011, untuk menilai keadaan kesehatan suatu negara secara menyeluruh, angka harapan hidup merupakan salah satu alat untuk mengevaluasi kinerja pemerintah dalam meningkatkan kesejahteraan penduduk pada umumnya, dan meningkatkan derajat kesehatan pada khususnya. Menurut laman Kementerian Sosial Republik Indonesia angka harapan hidup adalah angka rata-rata lamanya penduduk suatu kelompok atau negara untuk dapat bertahan hidup. Idealnya angka harapan hidup dihitung berdasarkan angka kematian menurut umur (age spesific death/ASDR) yang datanya diperoleh dari catatan registrasi kematian.

Kementerian Kesehatan Republik Indonesia melalui artikel dalam laman Departemen Kesehatan juga mengupayakan untuk menekan angka kematian di Indonesia. Kemajuan teknologi kedokteran, jaminan kesehatan yang baik, dan kesadaran dalam pencegahan penyakit akan meningkatkan angka harapan hidup. Dalam hal tersebut, dokter spesialis yang bergerak dalam bidang pelayanan kesehatan di Indonesia dan dianggap ahlinya dalam spesialis kesehatan tertentu juga punya tanggung jawab terhadap pasien-pasiennya untuk menghindari kejadian pasiennya meninggal dunia.

Tuntutan seorang dokter spesialis yang merupakan harapan bagi pasien dan kerabat pasien dalam keberhasilan penanganan maupun penyembuhan, sedikit banyak membuat dokter spesialis mengalami situasi dan kondisi yang emosional ketika pasiennya meninggal dunia. Seperti yang dirasakan oleh salah satu informan dari hasil wawancara pada 22 Februari 2018, dokter spesialis tersebut pernah merasa sedih dan gagal ketika pasien yang ditangani meninggal dan keluarga pasien marah kepada dokter tersebut.

Hampir dua pertiga dokter di AS mengatakan mereka kelelahan, depresi atau keduanya. Mereka bertugas untuk menyembuhkan kesehatan kita, tapi mereka sendiri menderita kejenuhan. Para dokter memikirkan bagaimana menumbuhkan kesejahteraan emosional untuk penyedia layanan kesehatan. Jika penyedia layanan kesehatan tidak sehat, sulit untuk bagi mereka untuk menyembuhkan para pasien (ttps://Bigthink.com).

Hasil Penelitian Krisiana dan Putri (2017) Hubungan antara Hardiness dan Regulasi Emosi Pada Perawat Rumah Sakit Usada Insani Kota Tangerang didapatkan hasil bahwa ada hubungan positif yang signifikan antara hardiness dan regulasi emosi pada perawat RS Usada Insani Kota Tangerang.

Keterampilan dalam meregulasi emosi merupakan keterampilan penting yang harus dimiliki oleh seorang dokter spesialis. Gross dan Thompson (2007) regulasi emosi adalah serangkaian proses emosi diatur sesuai dengan tujuan individu, pengaturan emosi positif maupun negatif baik dengan cara otomatis atau dikontrol, disadari atau tidak disadari dan melibatkan banyak komponen yang bekerja terus menerus sepanjang waktu.

Gross dan Thompson (dalam Zuraidha, 2012) menjelaskan regulasi emosi terdiri dari dua aspek yaitu mekanisme regulasi emosi yang bersifat terkontrol dan reaksi emosional 
terhadap stres bersifat otomatis yang kemudian dua aspek tersebut dibagi kedalam dua bentuk strategi yaitu cognitive reappraisal dan expressive suppression (Gross \& John, 2003). Expressive suppression merupakan sebuah bentuk modulasi respon yang melibatkan individu mengurangi perilaku emosi yang ekspresif ketika individu sudah dalam keadaan emosional. Supression merupakan response-focused strategy yang datangnya relatif lambat dalam proses pembangkitan emosi dan memodifikasi aspek perilaku dari kecenderungan respon emosi. Supression dapat efektif dalam mengurangi ekspresi perilaku oleh emosi negatif akan tetapi juga memiliki efek samping yang tidak diharapkan yaitu mengawasi emosi-emosi positif yang ketat (Gross \& Thompson, 2003)

Menurut Kordva dan Vegy (dalam Sajadi, Khaltbari, Panahi, \& Sajadi, 2012) setiap individu tidak akan memiliki reaksi emosional yang sama dalam satu situasi. Perbedaan kemampuan meregulasi emosi setiap orang dinyatakan Gross (dalam Nisfiannoor \& Kartika, 2004) merupakan dasar dalam pembentukan kepribadian serta menjadi sumber penting dari perbedaan-perbedaan individual. Kepribadian seseorang akan menentukan reaksi yang muncul terhadap suatu masalah yang dihadapinya. Gross (dalam Lewis, Jones, Barret, 2008) berpendapat bahwa kepribadian merupakah salah satu faktor dari faktor lainnya yang memengaruhi regulasi emosi yaitu budaya, religiusitas, usia, jenis kelamin, dan kondisi psikologis.

Penelitian yang dilakukan oleh Parkes (dalam Strutton, Lumpkin \& Pelton, 1995), menunjukkan bahwa kepribadian mempengaruhi persepsi individu dalam melihat suatu masalah, dan karakteristik kepribadian yang dapat mengurangi dampak stres dari suatu permasalahan adalah kepribadian yang memiliki kemampuan untuk dapat menghadapi sumber stres dan mampu melakukan kontrol terhadap situasi yang menimbulkan stres tersebut. Kobasa (dalam Kreitner \& Kinicki, 2005), mengidentifikasi karakteristik individu yang dapat menetralisir stres dalam bekerja. Karakter tersebut disebut sebagai hardiness, yang melibatkan kemampuan untuk mempersepsi atau perilaku mengubah stres negatif menjadi tantangan positif. Menurut Kobasa (dalam Taylor, Peplau \& Sears, 2003) kepribadian hardiness adalah suatu kumpulan perilaku yang memungkinkan individu untuk memiliki ketahanan terhadap tekanan psikologis. Kobasa (dalam Khaledian, Khasavand, \& Pour, 2013) mengatakan bahwa hardiness dibentuk oleh tiga aspek, yaitu commitment, control, dan challenge. Komitmen membuat individu yakin bahwa individu dapat mengendalikan peristiwa yang mereka temui. Kontrol membuat individu sangat berkomitmen terhadap aktivitas dalam kehidupan, dan tantangan berbicara mengenai bagaimana individu memperlakukan perubahan dalam kehidupan sebagai sebuah tantangan. Kobasa (dalam Ivancevich, 2007) mengungkapkan komponen-komponen tersebut berperan sebagai mediator dari efek stres dan mengenali kondisi yang ditimbulkan untuk mengubah dan menurunkan akibat dari stres tersebut di dalam kehidupan. 
Secara konseptual, menurut Maddi dan Kobasa (dalam Bartone, 2006) kepribadian hardiness adalah dimensi kepribadian yang berkembang pada awal kehidupan dan cukup stabil dari waktu ke waktu, meskipun memungkinkan untuk berubah dan dilatih dalam kondisi tertentu. Individu dengan kepribadian hardiness yang tinggi memiliki sense of life dan komitmen kerja yang tinggi, kontrol diri yang besar, dan lebih terbuka terhadap perubahan dan tantangan dalam hidup. Mereka cenderung menafsirkan pengalaman stres dan menyakitkan sebagai aspek normal keberadaan, bagian dari hidup yang secara keseluruhan menarik dan berharga. Menurut Kusumaningtyas (2015) bekerja tidak lepas dari stresoryang akan menimbulkan stres kerja dan berdampak pada pengolahan emosi negatif. Dokter spesialis yang merupakan pekerja di sektor kesehatan juga dalam pekerjaannya dapat terkena stres, yaitu konflik dengan tenaga medis lain, diskriminasi, beban kerja yang tinggi dengan shift karena dokter dituntut untuk siaga 24 jam ketika ada pasien yang tidak terduga, menghadapi pasien, keluarga pasien, dan kematian pasien. Stresor yang dialami dokter spesialis dapat terjadi ketika pasien yang ditangani meninggal dunia. Dikutip dari perkataan Asisten Profesor Greg Crawford dan Asisten Profesor Pengobatan Paliatif di Fakultas Medis Universitas Adelaide dalam artikel yang ditulis oleh Dr. Caren Andexer pada 26 November 2016 di laman Monthly Index of Medical Specialities (MIMS), bahwa kematian pasien dapat menjadi saat yang paling emosional dan mengisolasi pengalaman seorang dokter dan beberapa dapat menganggapnya sebagai kegagalan profesi mereka. Hasil wawancara pada salah satu anggota keluarga dokter spesialis pada tanggal 8 Maret 2018 juga mengungkapkan bahwa ayahnya yang merupakan dokter spesialis jarang membicarakan tentang pasiennya di rumah, namun ada saat-saat di mana ayahnya pulang, lalu menangis karena ada pasien yang tak bisa ia selamatkan.

Menurut penelitian Zheng, Lee, dan Bloomer (2017) berurusan dengan kematian seorang pasien dipandang sebagai salah satu yang paling menuntut dan menantang dalam praktik klinis karena yang menangani dianggap tidak kompeten dalam mengatasi kematian pasien, tidak memadai dalam mendukung pasien yang akhirnya meninggal, dan meminimalkan kualitas perawatan akhir kehidupan. Kematian pasien kadang-kadang mempengaruhi setiap yang terlibat secara emosional, fisik dan profesional,termasuk dokter spesialis (Hinderer, 2012). Proses berurusan dengan kematian pasien, karena kematian adalah pengalaman pribadi, dirasakan berbeda oleh masing-masing dokter spesialis yang menangani. Pada wawancara kepada dua dokter spesialis pada 22 Februari 2018, satu diantaranya merasakan kondisi tertekan karena pernah menangani pasien yang kondisi pasien tersebut dinyatakan bagus namun setelah dilakukan penanganan akhirnya meninggal dunia. Menurut Stansbury dan Gunnar (dalam Burgess, 2006) situasi dan kondisi yang penuh tekanan (seperti yang dialami dokter spesialis ketika menangani pasien meninggal dunia) berpotensial menimbulkan emosi-emosi yang negatif. Saat seseorang mengalami situasi yang 
penuh tekanan, regulasi emosi digunakan untuk mengurangi atau menghilangkan emosi negatif yang timbul (Gross \& John, 2003 dalam Burgess, 2006). Salah satu alasan individu yang memiliki kepribadian hardiness dapat bertahan dalam situasi stres adalah karena kemampuannya dalam meregulasi emosi-emosi negatif.

Penelitian terdahulu yang dapat mendukung penelitian ini adalah penelitian yang dilakukan oleh Kusumaningtyas (2015) yaitu terdapat korelasi yang positif dan signifikan antara hardiness dengan kemampuan regulasi emosi pada perawat rumah sakit swasta di Kota Bandung. Dawenan, Akbar, dan Yuniarrahmah (2014) juga meneliti mengenai hubungan antara regulasi emosi dengan hardiness yang menunjukan bahwa ada korelasi yang bersifat positif antara regulasi emosi dengan hardiness pada atlet mahasiswa di Banjarbaru dan penelitian yang dilakukan oleh Ingranurindani (2008) menunjukkan bahwa terdapat hubungan yang signifikan dan positif antara hardinessdengan strategi regulasi emosi secara kognitif pada ibu bekerja.

Pada dokter spesialis, mereka dituntut untuk menjalani rangkaian tanggung jawab yang besar menyangkut keselamatan nyawa banyak orang (Mirazinta \& Rohmiyanti, 2015). Penelitian yang meneliti profesi dokter spesialis sebagai subjek penelitian dan meneliti sisi psikologis dari profesi dokter terutama yang pernah menangani pasien meninggal dunia masih jarang ditemui. Menurut Emaliyawati (2011) topik-topik mengenai kematian belum banyak dipelajari, kemungkinan besar karena kecenderungan sifat dasar manusia yang menganggap tabu dalam membahas hal-hal yang berkaitan dengan kematian yang bertentangan dengan tujuan dari usaha medis untuk menyembuhkan orang yang sakit. Berdasarkan uraian diatas maka dari itu penulis merasa tertarik untuk mengetahui secara empiris mengenai hubungan kepribadian hardiness dengan regulasi emosi pada dokter spesialis yang pernah menangani pasien meninggal dunia.

\section{METODE PENELITIAN}

\section{A. Desain Penelitian}

Dalam penelitian ini menggunakan pendekatan kuantitatif dengan desain penelitian korelasional. Variabel bebas $(\mathrm{X})$ adalah kepribadian hardiness dan variabel terikat $(\mathrm{Y})$ adalah regulasi emosi.

B. Definisi Operasional

1. Kepribadian Hardiness

Kepribadian hardiness adalah variabel kepribadian dari suatu kumpulan perilaku untuk cenderung melibatkan diri dalam apapun yang dilakukan maupun yang dihadapi, respon yang positif terhadap tantangan, dan kontrol diri sehingga memungkinkan individu untuk memiliki ketahanan terhadap tekanan psikologis (Kobasadalam Taylor, Peplau \& Sears, 2003). 


\section{Regulasi Emosi}

Gross dan Thompson (2007) regulasi emosi adalah serangkaian proses emosi diatur sesuai dengan tujuan individu, pengaturan emosi positif maupun negatif baik dengan cara otomatis atau dikontrol, disadari atau tidak disadari dan melibatkan banyak komponen yang bekerja terus menerus sepanjang waktu.

\section{Partisipan}

Partisipan dalam penelitian ini adalah dokter spesialis yang pernah menangani pasien meninggal dunia yang bekerja di 4 rumah sakit di daerah Kabupaten Pati, Jawa Tengah. Teknik pengambilan sampel dilakukan dengan teknik accidental sampling yaitu pengambilan sampel pada siapa saja yang kebetulan bertemu dengan peneliti di 4 rumah sakit tersebut, dapat digunakan sebagai sampel bila orang yang ditemui sesuai dengan karakteristik subjek. Adapun karakteristik subjek dalam penelitian ini adalah dokter spesialis yang pernah menangani pasien meninggal dunia dengan menangani pasien secara langsung dalam tindakan (seperti operasi), pengobatan ataupun perawatan, dan pasien tersebut meninggal dunia ketika dalam tindakan, pengobatan atau perawatan dokter tersebut.

Keseluruhan partisipan diberikan pertanyaan singkat terbuka dalam skala psikologi yang disebar untuk menentukan dokter spesialis mana yang pernah menangani pasien meninggal dunia. Dari jawaban tersebut, ditemukan 40 dokter spesialis yang pernah menangani pasien meninggal dunia. Maka dari itu, sampel dari penelitian ini berjumlah 40 dokter spesialis.

D. Instrumen Pengumpulan Data

Instrumen pengumpulan data yang digunakan oleh peneliti yaitu dengan menggunakan skala psikologi. Dalam penelitian ini peneliti menggunakan dua skala psikologi yaitu :

\section{Kepribadian Hardiness}

Pada penelitian ini kepribadian hardiness diukur dengan menggunakan Dispositional Resilience Scale 15-Revised yang telah diadaptasi oleh Lukman (2008) dari DRS 45 aitem yang dikembangkan oleh Bartone (1989) berdasarkan aspek yang dikemukakan oleh Kobasa. Hasil uji reliabilitas alat ukur DRS 15-R versi Bahasa Indonesia ini tergolong baik, dengan koefisien sebesar 0,67 . DRS $15-R$ terdiri dari 15 aitem pertanyaan, yaitu 5 aitem untuk mengukur commitment, 5 aitem untuk mengukur control, 5 aitem untuk mengukur challenge.

Respon jawaban dalam skala model likert ini terdapat 4 pilihan jawaban mulai dari Sangat Tidak Sesuai (STS), Tidak Sesuai (TS), Sesuai (S), dan Sangat Sesuai (SS). Berdasarkan hasil uji analisa aitem oleh peneliti, skala kepribadian hardiness memperoleh reliabilitas 0,755 dengan jumlah 13 aitem. Koefisien korelasi aitem total bergerak dari 0,341 hingga 0,717 . 


\section{Regulasi Emosi}

Pengukuran regulasi emosi menggunakan skala Emotion Regulation Questionnaire (ERQ) yang disusun oleh John dan Gross (2003). Skala ini terdiri dari 10 aitem, yang mengukur kecenderungan subjek dalam melakukan regulasi emosi terdiri dari 2 cara yaitu Cognitive Reappraisal dan Expressive Suppression. Dari 10 aitem, 6 aitem mengukur Cognitive Reappraisal dan 4 aitem mengukur Expressive Suppression.

Respon jawaban dalam alat ukur ini menggunakan skala Likert 4 poin, mulai dari Sangat Tidak Sesuai (STS), Tidak Sesuai (TS), Sesuai (S), dan Sangat Sesuai (SS). Emotion Regulation Questionnaire (ERQ) yang digunakan pada penelitian ini telah dilakukan uji coba pada penelitian sebelumnya oleh Mayangsari dan Ranakusuma (2014) dengan reliabilitas sebesar 0,811. Berdasarkan hasil uji analisa aitem oleh peneliti, skala regulasi emosi memperoleh reliabilitas 0,758 dengan jumlah 13 aitem. Koefisien korelasi aitem total bergerak dari 0,345 hingga 0,813 .

\section{HASIL DAN PEMBAHASAN}

A. Analisa Deskriptif

Tabel 1. Kategorisasi Kepribadian Hardiness

\begin{tabular}{llllll}
\hline Kategori & Interval & Frekuensi & $\%$ & Mean & SD \\
\hline Sangat Tinggi & $42,25 \leq X \leq 52$ & 14 & $35 \%$ & & \\
Tinggi & $32,5 \leq X 42,25$ & 26 & $65 \%$ & 41,35 & 3,79 \\
Rendah & $22,75 \leq X<32,5$ & 0 & $0 \%$ & & \\
Sangat Rendah & $13 \leq X<22,75$ & 0 & $0 \%$ & & \\
\hline
\end{tabular}

Tabel di atas menunjukkan bahwa mayoritas dokter spesialis memiliki tingkat kepribadian hardiness dalam kategori tinggi 26 dokter spesialis (65\%), kategori sangat tinggi 14 dokter spesialis (35\%), kategori rendah dan sangat rendah 0 dokter spesialis( $0 \%)$.

Tabel 2. Kategorisasi Regulasi Emosi

\begin{tabular}{llllll}
\hline Kategori & Interval & Frekuensi & $\%$ & Mean & SD \\
\hline Sangat Tinggi & $29,25 \leq X \leq 36$ & 4 & $10 \%$ & & \\
Tinggi & $22,5 \leq X<29,25$ & 31 & $77,5 \%$ & & \\
Rendah & $15,75 \leq X<22,5$ & 4 & $10 \%$ & 25,97 & 3,24 \\
Sangat & & & & & \\
Rendah & $9 \leq X<15,75$ & 1 & $2,5 \%$ & & \\
\hline
\end{tabular}

Tabel di atas menunjukkan bahwa mayoritas dokter spesialis memiliki tingkat regulasi emosi dalam kategori tinggi31 dokter spesialis (77,5\%), kategori sangat tinggi 4 dokter spesialis (10\%), kategori rendah 4 dokter spesialis(10\%) dan kategori sangat rendah 1 dokter spesialis $(2,5 \%)$. 
B. Uji Asumsi

1. Uji Normalitas

Hasil dari uji normalitas menggunakan teknik analisis One Sample KolmogorovSmirnov Test, diperoleh taraf signifikansi padavariabel kepribadian hardiness sebesar 0,699 $(p>0,05)$ dan taraf signifikansi pada variabel regulasi emosi sebesar 0,169 $(p>0,05)$. Hasil tersebut menunjukkan bahwa variabel kepribadian hardiness dan variabel regulasi emosi berdistribusi normal.

Tabel 3. Uji Normalitas

One-Sample Kolmogorov-Smirnov Test

\begin{tabular}{llll}
\hline & & hardiness & regulasiemosi \\
\hline $\mathrm{N}$ & & 40 & 40 \\
Normal Parameters ${ }^{\mathrm{a}, \mathrm{b}}$ & Mean & 41.35 & 25.98 \\
& Std. Deviation & 3.786 & 3.238 \\
\multirow{2}{*}{ Most Extreme Differences } & Absolute & .112 & .176 \\
& Positive & .112 & .176 \\
& Negative & -.063 & -.085 \\
Kolmogorov-Smirnov Z & & .707 & 1.112 \\
Asymp. Sig. (2-tailed) & & .699 & .169 \\
\hline
\end{tabular}

a. Test distribution is Normal.

\section{Uji Linieritas}

Hasil uji linieritas menunjukkan bahwa kedua variabel yaitu variabel kepribadian hardinessdan variabel regulasi emosi memiliki $F_{\text {beda }}$ sebesar 1,797 dengan signifikansi sebesar 0,100 $(p>0,05)$. Dengan demikian variabel kepribadian hardiness dan variabel regulasi emosi memiliki hubungan yang linear.

Tabel 4. Uji Linieritas

ANOVA Table

\begin{tabular}{|c|c|c|c|c|c|c|c|}
\hline & & & $\begin{array}{l}\text { Sum of } \\
\text { Squares }\end{array}$ & df & $\begin{array}{l}\text { Mean } \\
\text { Square }\end{array}$ & $\mathrm{F}$ & Sig. \\
\hline \multirow{5}{*}{$\begin{array}{l}\text { regulasiemosi } \\
\text { hardiness }\end{array}$} & \multirow{3}{*}{$\begin{array}{l}{ }^{*} \text { Between } \\
\text { Groups }\end{array}$} & (Combined) & 257.677 & 15 & 17.178 & 2.725 & .014 \\
\hline & & Linearity & 99.069 & 1 & 99.069 & 15.715 & .001 \\
\hline & & $\begin{array}{l}\text { Deviation } \\
\text { from } \\
\text { Linearity }\end{array}$ & 158.608 & 14 & 11.329 & 1.797 & .100 \\
\hline & \multicolumn{2}{|l|}{ Within Groups } & 151.298 & 24 & 6.304 & & \\
\hline & \multicolumn{2}{|l|}{ Total } & 408.975 & 39 & & & \\
\hline
\end{tabular}


3. Uji Korelasi

Berdasarkan hasil perhitungan uji korelasi dengan teknik Product Moment - Pearson diperoleh koefisien korelasi antara kepribadian hardiness dengan regulasi emosi sebesar 0,492 dengan signifikansi $0,001(p<0,05)$ yang berarti bahwa terdapat hubungan positif yang signifikan antara kepribadian hardiness dengan regulasi emosi. Hasil pengujian dapat dilihat pada tabel berikut ini :

Tabel 5. Uji Korelasi

Correlations

\begin{tabular}{llll}
\hline & & Hardiness & Regulasiemosi \\
\hline hardiness & Pearson Correlation & 1 & $.492^{* *}$ \\
& Sig. (1-tailed) & & .001 \\
& $\mathrm{~N}$ & 40 & 40 \\
\hline regulasiemosi & Pearson Correlation & $.492^{* *}$ & 1 \\
& Sig. (1-tailed) & .001 & \\
& $\mathrm{~N}$ & 40 & 40 \\
\hline
\end{tabular}

${ }^{* *}$. Correlation is significant at the 0.01 level (1-tailed).

\section{HASIL DAN PEMBAHASAN}

Berdasarkan hasil pengujian terhadap hipotesis penelitian diperoleh hasil terdapat hubungan positif yang signifikan antara kepribadian hardiness dengan regulasi emosi pada dokter spesialis yang pernah menangani pasien meninggal dunia, dengan demikian hipotesis diterima. Hasil uji hipotesis menunjukkan koefisien korelasi $(r)=0,492$ dengan sig. $=0,001(p$ $<0,05)$.

Hasil penelitian ini sesuai dengan penelitian yang dilakukan sebelumnya oleh Kusumaningtyas (2015) yang menemukan adanya hubungan positif yang signifikan antara kepribadian hardiness dengan regulasi emosipada perawat rumah sakit swasta di Kota Bandung. Semakin tinggi kepribadian hardiness yang dimiliki maka akan semakin tinggi pula regulasi emosi yang dimiliki. Begitu juga sebaliknya semakin rendah kepribadian hardiness yang dimiliki, maka akan semakin rendah pula regulasi emosi yang dimiliki.

Saat seseorang mengalami situasi yang penuh tekanan, regulasi emosi digunakan untuk mengurangi atau menghilangkan emosi negatif yang timbul (Gross \& John, 2003 dalam Burgess, 2006). Kepribadian hardiness mempunyai kemampuan dalam mengatasi situasi yang penuh dengan emosi-emosi negatif di dalam hidup mereka, sehingga pada akhirnya akan dapat meningkatkan kesejahteraan psikologis dan fisiologis mereka. Salah satu alasan individu yang memiliki kepribadian hardiness dapat bertahan dalam situasi stres adalah 
karena kemampuannya dalam meregulasi emosi-emosi negatif (Aspinwell \& Brunhart, 2000 dalam Wong, 2005).

Sesuai dengan hasil penelitian ini, ditemukan bahwa kepribadian hardiness yang dimiliki oleh dokter spesialis yang pernah menangani pasien meninggal dunia memiliki hubungan pada tinggi rendahnya regulasi emosi. Adapun hasil uji koefisien determinasi diketahui bahwa kepribadian hardiness memberikan andil sebesar $24,2 \%$ terhadap regulasi emosi sedangkan $75,8 \%$ dipengaruhi oleh faktor lainnya seperti budaya, religiusitas, usia, jenis kelamin, dan kondisi psikologis (Gross, dalam Lewis, dkk, 2008).

Dalam penelitian ini peneliti menemukan sebanyak $77,5 \%$ regulasi emosi dokter spesialis yang pernah menangani pasien meninggal dunia berada pada kategori tinggi. Hal tersebut menunjukkan bahwa dokter spesialis yang pernah menangani pasien meninggal dunia mampu untuk memenuhi aspek-aspek regulasi emosi yaitu lebih mampu menunjukkan emosi positif dan menekan emosi negatif yang akan timbul. Dapat dikatakan bahwa dokter spesialis yang pernah menangani pasien meninggal dunia mampu menempatkan atau mengatur emosi yang sesuai dalam menjalankan tugasnya melayani pasien. Berdasarkan fenomena yang terjadi, dokter spesialis diharuskan selalu memberikan emosi yang positif ketika berhadapan dengan pasien. Hal tersebut sejalan dengan hasil penelitian yang dilakukan oleh John dan Gross (2003) yang mengatakan bahwa individu yang menggunakan regulasi emosi akan lebih mudah mengeluarkan emosi positif dan menekan emosi negatif yang dimilikinya.Untuk hasil persentase tingkat kepribadian hardiness menunjukkan sebanyak $65 \%$ dokter spesialis yang pernah menangani pasien meninggal dunia berada pada kategori tinggi, hal inidapat diinterpretasikan bahwa dokter spesialis yang pernah menangani pasien meninggal dunia memiliki kepribadian hardiness dan tingkat kepribadian hardiness baik. Hasil ini dapat dikaitkan dengan hasil penelitian yang dilakukan oleh Funk dan Houston (1987) dalam Kardum, Krapic, dan Knezevic (2012) yang menyatakan bahwa kepribadian hardiness dapat merefleksikan stabilitas emosi dengan baik.

\section{SIMPULAN DAN SARAN}

\section{Kesimpulan}

Dari hasil penelitian ini dapat disimpulkan bahwa ada hubungan positif yang signifikan antara kepribadian hardiness dengan regulasi emosi pada dokter spesialis yang pernah menangani pasien meninggal dunia. Artinya semakin tinggi kepribadian hardiness maka semakin tinggi regulasi emosi pada dokter spesialis yang pernah menangani pasien meninggal dunia, sebaliknya jika kepribadian hardiness rendah maka regulasi emosi pada dokter spesialis yang pernah menangani pasien meninggal dunia akan rendah.

\section{Saran}

1. Bagi Dokter Spesialis 
Para dokter spesialis diharapkan melatih dan mempertahankan kemampuan regulasi emosi dalam bentuk kontrol emosi positif maupun negatif agar dapat mengelola emosi dan mengekspresikan emosi dengan tepat terkait dengan tuntutan kerja sebagai dokter spesialis yang mengharuskan untuk menjaga komunikasi yang baik dengan pasien, keluarga pasien dan tim kesehatan lainnya.

Para dokter spesialis perlu melatih dan memelihara kemampuan ketahanan (hardiness) untuk menganggap stres kerja seperti kematian pasien dan tuntutan lainnya sebagai tantangan dalam pekerjaannya.

Para dokter spesialis tetap mempertahankan empati kepada pasien dan keluarga pasien untuk meningkatkan pelayanan kesehatan dan proses penyembuhan yang diberikan karena pasien dan keluarga pasien terdiri dari berbagai macam latar belakang sosial, pendidikan, dan eknonomi yang berbeda.

\section{Bagi Rumah Sakit}

Hasil penelitian didapatkan bahwa regulasi emosi pada kecenderungan dokter spesialis tergolong tinggi, hal ini dapat ditingkatkan dan dipertahankan dengan membuat program dari rumah sakit seperti pelatihan ketrampilan regulasi emosi sebagai program untuk penanganan stres yang dihadapkan pada dokter spesialis.

Pihak rumah sakit dapat mempertimbangkan variabel hardiness dalam mengidentifikasi seputar performa kerja para dokter spesisialis dan membuat treatmen jika diperlukan. Karena ketiga aspek kepribadian hardiness menjelaskan bagaimana individu nantinya dapat mengendalikan dan memberikan reaksi yang tepat, memberikan usaha yang terbaik, dan membuat kemajuan dalam situasi buruk dalam pekerjaannya.

\section{Bagi Penelitian Selanjutnya}

Bagi peneliti selanjutnya diharapkan untuk memperbesar jumlah sampel dengan kriteria subjek dokter spesialis yang lebih spesifik seperti lamanya menjadi dokter spesialis dan dokter spesialis-spesialis tertentu di karenakan perbedaan spesialis membuat perbedaan rlsiko dan frekuensi menangani pasien meninggal dunia.

Jika peneliti berikutnya hendak meneliti variabel regulasi emosi, peneliti dapat mengkaitkan faktor-faktor lain yang berhubungan dengan regulasi emosi seperti budaya, religiusitas, usia, jenis kelamin, dan kondisi psikologis.

Peneliti selanjutnya diharapkan mempertimbangkan dalam mengatur waktu yang lebih tepat pada saat pengambilan data kepada dokter spesialis dikarenakan waktu dokter spesialis yang padat untuk melayani pasien ketika berada di Rumah Sakit, serta memakai alternatif penyebaran angket secara online sehingga dokter spesialis akan lebih leluasa dan memiliki situasi yang kondusif untuk mengisi angket. 


\section{DAFTAR PUSTAKA}

Andexer, C. (2016). Ketika pasien meninggal: Apakah seorang tenaga kesehatan perlu datang ke prosesi pemakaman pasien?. Mims.com. Diunduh pada tanggal 5 Juli 2018

Bartone, P.T. (2006). Resilience Under Military Operasional Stress: Can Leaders Influence Hardiness?. Military Psychology, 18, 131-148.

Burgess, L.M. (2006). Emotion regulation and behavioral, emotional, and cardiovascular responses to interpersonal stress. Disertasi. Ann Arbor, MI : UMI.

Dawenan, R.C., Akbar, S.N., Yuniarrahmah, E. (2014). Hubungan antara Regulasi Emosi dengan Hardiness pada Atlet Mahasiswa Banjarbaru. Jurnal Ecopsy, 1(4).

Emaliyawati, E. (2011). Interaksi Pasien, Keluarga dan Petugas Kesehatan dalam Perawatan Akhir-Hidup Pasien Terminal. Nursing Journal of Padjajaran University, 12(2).

Fitroh, S.F. (2011). Hubungan Antara Kematangan Emosi dan Hardiness dengan Penyesuaian Diri Menantu Perempuan yang Tinggal Dirumah Ibu Mertua. Jurnal Psikologi Islam,8(1).

Gross, J.J., \& John, O.P. (2003). Individual differences in two emotion regulation processes: Implications for affect, relationships, and well-being. Journal of Personality and Social Psychology, 85, 348-362.

Gross, J.J., \& Thompson, R.A. (2007). Handbook of emotion regulation. New York : Guilford Press.

Gross, J.J., \& John, O.P. (2013). Handbook of regulation emotion. New York: Guilford Press.

Hinderer, K.A. (2012). Reactions to patient death: The lived experience of critical care nurses. DCCN-Dimensions of Critical Care Nursing, 31, 252-259.

Ingranurindani, B. (2008). Hubungan antara strategi regulasi emosi secara kognitif dengan hardiness pada ibu bekerja. Skripsi (tidak diterbitkan). Depok: Universitas Indonesia.

Ivanevich, J. (2007). Human Resources Management. McGraw Hill International Edition.

Kardum, Krapić \& Knežević. (2012). The structure of hardiness, its measurement invariance across gender and relationships with personality traits and mental health outcomes. Psychological Topics Journal,21(3), 487-507.

Khaledian. Hasanvand. Pour. (2013). The Relationship of Psychological Hardiness with Workholism.International Letters of Social and Humanistic Sciences. 5, 1-9. ISSN 2300-2697.

Kreitner, R., \& Kinicki, A. (2005). Perilaku organisasi. Buku 2. Edisi 5. Alih Bahasa : Erly Suandy. Jakarta: Salemba Empat.

Ginanti, G.G , Kristiana, I.F (2017). Hubungan antara Hardiness dan Regulasi Emosi Pada Perawat Rumah Sakit Usada Insani Kota Tangerang. Jurnal .Semarang : Universitas Diponegoro. 
Kusumaningtyas, A.R. (2015). Hubungan antara kepribadian hardiness dengan kemampuan regulasi emosi perawat rumah sakit swasta di Kota Bandung. Skripsi (tidak diterbitkan). Bandung: Universitas Pendidikan Indonesia.

Lewis, M., Jones, J.M.H., Barret, L.F. (2008).Handbook of emotion third edition, New York : Published Guilford Press.

Lukman, A. (2008). Adaptasi dispositional resilience scale-short form pada pramu sosial usia dewasa muda di Panti Sosial Bina Laras Harapan Sentosa. Thesis (tidak diterbitkan). Depok: Fakultas Psikologi Universitas Indonesia.

Mirazinta, Y.\& Rohmiyanti, Y. (2015). Studi literasi informasi mahasiswa koasisten Fakultas Kedokteran Universitas Diponegoro. Jurnal IImu Perpustakaan, 4(2).

Nisfianoor, M., Rostiana, Puspasari, T. (2004). Hubungan antara komitmen beragama dan subjective well-being pada remaja akhir di Uversitas Tarumanegara. Jurnal Psikologi, 2(1), 73-93.

Pangesti, A. (2012). Pengaruh konflik peran terhadap terjadinya burnout pada mahasiswa koass. Jurnal Penelitian dan Pengukuran Psikologi, 1(1).

Sajadi, S.K.,Panahi,Sajadi, N. (2012). The relationship between anxiety and emotion regulation with psychological hardiness in students. Journal of Annals of Biological Research, 3(10), 4964-4969.

of coping strategies. Journal of the Academy of Marketing Science, 23(2), 132-140.

Taylor, S.E., Peplau, L.A., \& Sears, D.O. (2003). Social psychology (11th ed.). Upper Saddle River, NJ: Prentice Hall.

Wong, C.F. (2005). Regulation of negative emotions in response to an acute stressor among breast cancer survivors. Disertasi. Ann Arbor, MI : UMI.

Zheng, R., Lee, S.F., Bloomer, M.J. (2017). How nurses cope with patient death: A systematic review and qualitative meta-synthesis. Journal of Clinical Nursing, 27(1-2), e39-e49.

Zuraidha, V.N. (2012). Regulasi emosi dan happiness pada siswa kelas $X$ program reguler dan akselerasi SMA Negeri 3 Malang. Skripsi (tidak diterbitkan). Malang: Fakultas Psikologi UIN Maulana Malik Ibrahim. 